\title{
PHOTOCHEMICAL STUDY OF TRIS(ETHYLXANTHATO) IRON(III) IN DIFFERENT ORGANIC SOLVENTS
}

\author{
Nasser Shalan \\ Department of Chemistry, College of Science for Women, Baghdad University, \\ Baghdad-Iraq.
}

\begin{abstract}
The photochemistry of Tris(ethylxanthato) iron(III) was studied in five organic solvents: dimethyl sulfoxide (DMSO), methanol, acetone, ethyl acetate and Benzene .Monochromatic light of wavelength $365 \mathrm{~nm}$ was used for the irradiation process at $25{ }^{\circ} \mathrm{C}$. Uv-visible spectral changes and other observations indicated an intra oxidation-reduction reaction occuring during the photolysis of $\mathrm{Fe}(\mathrm{etx})_{3}$ complex, with homolytic scission of $\mathrm{Fe}-\mathrm{S}$ bond. The quantum yield $\left(\phi_{\mathrm{d}}\right)$, rate of photodecomption and reactivity ratio $\left(\mathrm{k}_{2} / \mathrm{k}_{-1}\right)$ were determined in each solvent. These values always increase as the polarity of the solvent increased and following the order.
\end{abstract}

\section{DMSO $>$ Methanol $>$ Acetone $>$ Ethyl acetate $>$ Benzene}

According to the experimental results obtained, the mechanism of photodecomption of these complexes under the applied conditions was proposed.

\section{Introduction}

The photochemistry of transition metal chelate has been studied extensively during the last decades (1-5) with the following main interesting applications :

1- Photochemical conversion and storage of solar energy as a photosensitizer in hydrogen production from water splitting, phototoxiation of $\mathrm{CO}_{2}$ and photo galvanic cell ${ }^{(6,7)}$

2- Photoinitation of polymerization crosslinking of polymers ${ }^{(8-9)}$.

3- Photocatalysts for organic synthesis ${ }^{(10)}$.

4- Gasoline octane number improvers ${ }^{(11)}$.

5- Photostabilization of polymer and photoinducer for polymer degradation ${ }^{(12)}$. The redox reaction of $\mathrm{Fe}(\mathrm{acac})_{3}$ chelate complex was invesigated in polystyrene films as photosensitizer degradation ${ }^{(13)}$, (where acac $=4.2$ pentanedinate anion).

The photochemical decomposition of tris[N-(3-ol-1-methyl)butidene (amino) aniline]iron was also studied and the free radical generated was derived from the ligand .It is effectively initiating the photodegradation of polystyrene and poly(methyl methacrylate) films ${ }^{(14)}$. Aliwi and et al. ${ }^{(15)}$ reported the use of $\mathrm{Fe}$ (III) Schiff base chelate complexes for photodegradation of polystyrene. They for also observed that the photoredox process had occurred and the free radical responsible the initiation process was derived from the Schiff base ligand.

\section{Materials and Methods}

\section{A. Materials}

Tris(ethylxanthato) iron (III), This complex was prepared according the method reporting in literature. ${ }^{(16)}$

\section{B-Techniques}

All photolytic experiments were carried out in thermostated quartz cell of $10 \mathrm{~mm}$ path length. The photolytic solution was purged by argon gas (purity 99.9\%) for 20 minutes befor irradiated at $25{ }^{\circ} \mathrm{C}$.A light source, namely high pressure lamp (1000W.lwasa $\mathrm{Ki}$ Electric Co.Ltd., Japan) was used in conjugation with suitable quartz lens and filter (supplied by Kari-Korb C-mb $\mathrm{H}$, Germany) to give essentially a monochromatic beam of wavelength $365 \mathrm{~nm}$.Calibration of filter with the aid of spectrophotometer showed that the transmitted light was predominantly of wavelength $365 \mathrm{~nm}$. The incident light intensity was determined with ferrioxalate actinometer as described by Hatchard and Parker ${ }^{(17)}$. A Perkin -Elmer 1301 Uv-Vis. double beam spectrophotometer was employed to measure the optical densities and the spectral changes during irradiation experiments. 
Below is a schematic diagram of the used instrument:

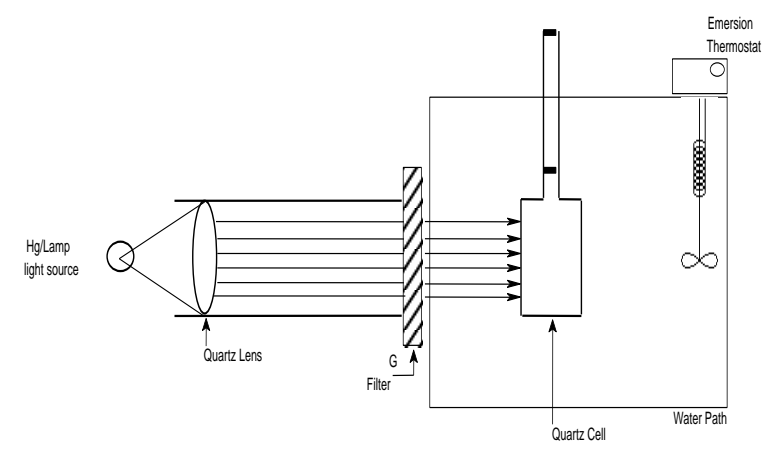

\section{Results and Discussion}

\section{$A$ - Uv-Visible spectrophotometr}

During irradiation time of chelate complexes the in dimethyl sulfoxide (DMSO), methanol, acetone, ethyl acetate and Benzene at $25{ }^{\circ} \mathrm{C}$, the colour was changes gradually from brown to brown-yellow in all solvents. The complexes spectrum changes with irradiation time, showing a decrease in the absorbance intensity in the visible region between wavelengths 400 to $800 \mathrm{~nm}$., at high concentration of the complex solution. The absorbance intensity between 200-400 nm. also decreased with irradiation time at lower concentration of the complexes.

\section{B-Identification of the photolytic products}

Identification methods are adopted to identify the photolytic products. Solution of $\mathrm{Fe}(\mathrm{etx})_{3}$ in benzene free from carbon disulfide, was irradiated for about 50 hours at $\lambda_{\text {irr }}=365$ $\mathrm{nm}$. (at $25{ }^{\circ} \mathrm{C}$ ). The complex fragmented to $\left(\mathrm{C}_{2} \mathrm{H}_{5} \mathrm{OCS}_{2}\right)_{2} \mathrm{Fe}(\mathrm{II})$ and xanthate radical as the first step of the decomposition as shown in equations (2).

Xanthate radical combines with the same radical as shown in equation (3), a positive test obtained for $\mathrm{S}-\mathrm{S}$ bond, which indicated the formation of the compound to expect this compound formed.

Xanthate radical abstract hydrogen atom from solvent molecule as shown in equation below a positive test obtained for S-H bond, which indicated the formation of the expect xanthic acid equation (4).

Also, xanthate radical fragmented to carbon disulfide and ethoxy radical as shown in equation (5).

1. $\left.\left(\mathrm{C}_{2} \mathrm{H}_{5} \mathrm{OCS}\right)_{2} \mathrm{Fe}, \mathrm{C}-\mathrm{OC}_{2} \mathrm{H}_{5} \frac{\mathrm{K}_{1}}{365 \mathrm{rm}} \cdot\left(\mathrm{C}_{2} \mathrm{H}_{5} \bigcirc \mathrm{CS}_{2}\right)_{2} \mathrm{Fe}_{\mathrm{S}}^{\mathrm{S}} \mathrm{C}-\mathrm{OC}_{2} \mathrm{H}_{5}\right]^{*}$

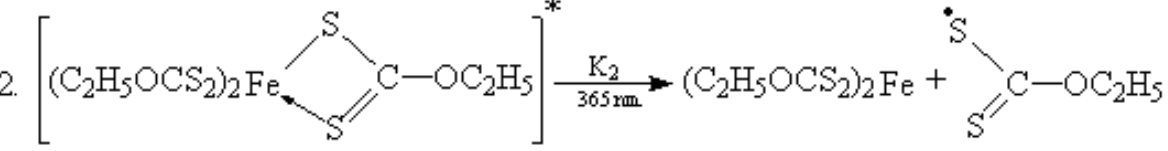

3. $\mathrm{C}_{2} \mathrm{H}_{5} \mathrm{O}-\mathrm{C}_{\mathrm{S}^{\prime}}^{\dot{\mathrm{S}}}+\underset{\mathrm{S}}{\mathrm{S}} \mathrm{C}-\mathrm{OC}_{2} \mathrm{H}_{5} \frac{\mathrm{K}_{3}}{365 \mathrm{~mm}}-\mathrm{C}_{2} \mathrm{H}_{5} \mathrm{O}-\mathrm{C}_{\searrow_{\mathrm{S}}} \overbrace{\mathrm{S}}^{\mathrm{C}-\mathrm{OC}_{2} \mathrm{H}_{5}}$

4. $\mathrm{C}_{2} \mathrm{H}_{5} \mathrm{O}-\mathrm{C}_{\bigwedge_{\mathrm{S}}}^{\dot{\mathrm{S}}}+\mathrm{HD} \stackrel{\mathrm{K}_{4}}{365 \mathrm{rm}}-\mathrm{C}_{2} \mathrm{H}_{5} \mathrm{O}-\mathrm{C}_{\mathrm{S}}^{\prime}$

5. $\mathrm{C}_{2} \mathrm{H}_{5} \mathrm{O}-\mathrm{C}_{\mathrm{S}}^{\dot{\mathrm{S}}} \frac{\mathrm{K}_{5}}{36 \text { rm. }}-\mathrm{CS}_{2}+\dot{\mathrm{O}} \mathrm{C}_{2} \mathrm{H}_{5}$ 
To ensure that $\mathrm{CS}_{2}$ was liberated in this photolytic reaction, $\mathrm{CS}_{2}$ analysis was carried out $^{(19)}$ and a positive test obtained. The same result was got upon irradiation of a solution of $\mathrm{Fe}(\mathrm{etx})_{3}$ complex in acetone solvent. Ethoxy radical obtained from the second step of decomposition of the complex abstracted a hydrogen atom from the solvent molecule (HD) and produced ethanol ${ }^{(20)}$. The radical derived from the solvent $\mathrm{D}$ could combine to form a dimer of solvent molecules (D-D) as shown in equations (6) and (7) respectively:

$$
\text { 6. } \mathrm{C}_{2} \mathrm{H}_{5} \dot{\mathrm{O}}+\mathrm{HD} \frac{\mathrm{K}_{6}}{365 \text { rm. }} \cdot \mathrm{C}_{2} \mathrm{H}_{5} \mathrm{OH}+\dot{\mathrm{D}}
$$

$$
\text { 7. } \mathrm{D}+\mathrm{D} \frac{\mathrm{K}_{7}}{365 \mathrm{rm} .} \mathrm{D}-\mathrm{D}
$$

Ethoxy radical $\mathrm{C}_{2} \mathrm{H}_{5} \mathrm{O}$ may be oxidize to aldehyde as shown in equations (8) and (9) respectively:

$$
\begin{aligned}
& \mathrm{C}_{2} \mathrm{H}_{5} \mathrm{O}^{*} \longrightarrow \mathrm{HCHO}+\dot{\mathrm{CH}_{3}} \\
& 2 \stackrel{\mathrm{CH}_{3}}{\longrightarrow} \mathrm{CH}_{3} \mathrm{CH}_{3}
\end{aligned}
$$

However, the test for formaldehyde was negative ${ }^{(18)}$. Apparently, the oxidation processes may stop after the ethoxy radical had abstracted hydrogen from the solvent.

Accordingly, one would except that an intra oxidation-reduction reaction occurs during the photolysis of $\mathrm{Fe}(\mathrm{etx})_{3}$ complex, with homolytic scission of $\mathrm{Fe}-\mathrm{S}$ bond to form radical fragments as explained above.

\section{C-Mechanism of the tris(ethylxanthato) iron(III) photodecomposition}

The Uv-Vis spectral changes, identification of the photolytic products and other observations, the following mechanism may be suggested for the photodecomposition process $(\mathrm{HD}=$ solvent molecule $)$.

$$
\begin{aligned}
& \text { The rate of decomposition }=I_{\mathrm{abs}}-\frac{\mathrm{I}_{\mathrm{abs}} \mathrm{k}_{-1}}{\mathrm{k}_{-1}+\mathrm{k}_{2}} \\
& \quad-\frac{\mathrm{d}\left[\mathrm{FeL}_{3}\right]}{\mathrm{dt}}=\ldots \ldots \ldots \ldots \ldots \ldots \ldots \ldots \ldots \text { (1) } \\
& \phi_{\mathrm{d}}=\frac{\text { rate of photodecomposition }}{\mathrm{I}_{\mathrm{abs}}} \ldots \ldots \ldots \ldots \text { (2) }
\end{aligned}
$$

$$
\frac{\mathrm{k}_{2}}{\mathrm{k}_{-1}}=\frac{\phi_{\mathrm{d}}}{1-\phi_{\mathrm{d}}}
$$

\section{D-The Kinetic Use of Uv-Visible Observations}

The decay of the $\mathrm{Fe}(\mathrm{etx})_{3}$ complex during irradiation at $365 \mathrm{~nm}$. And $25^{\circ} \mathrm{C}$ in different solvents, has been followed by monitoring the concentration of this complex spectrophototometrically.

From the variation of the concentration of iron(III) complex with time, the rate of photolysis of the complex was deduced. It was found that the change in the concentration varies exponentially with time, which indicates the first order relation of the photoreaction. Therefore from the logarithm plots of the $A_{t}-A \infty$ versus time, the values of the first order specific rate constant $\left(\mathrm{k}_{\mathrm{d}}\right)$ for the complex in different solvents was determined, where $A_{t}$ is the absorbance of the complex solution at selected wavelength, $A \infty$ is the absorbance of the same solution after prolonged irradiation. The variations of $\ln \left(A_{t}-A_{\infty}\right)$ with irradiation time (t) of complex. The specific rate constants $\left(\mathrm{k}_{\mathrm{d}}\right)$ for chelate complex were obtained. Table (1) shows the values of light intensity $\left(\mathrm{I}_{\mathrm{ab}}\right)$, the specific rate constant $\left(\mathrm{k}_{\mathrm{d}}\right)$, the quantum yield $\left(\phi_{\mathrm{d}}\right)$ and reactivity ratio $\left(\mathrm{k}_{2} / \mathrm{k}_{-1}\right)$ of the $\mathrm{Fe}(\mathrm{etx})_{3}$ complex in all solvents used under the same conditions.

The result shown in Table (1) generally indicate that the $\mathrm{k}_{\mathrm{d}}$ and $\phi_{\mathrm{d}}$ values are dependent on the type of solvent used. They always increase as the polarity of the solvents increase and follow the order

DMSO $>$ Methanol $>$ Acetone $>$ Ethyl acetate

\section{$>$ Benzene}

The variation of the values of quantum yield with dielectric constant value of solvent are shown in Fig. (1). These results in this, generally, indicate that $\phi_{\mathrm{d}}$ increases as the dielectric constant increases; and this might point out the ionic nature of the excited transition state of the $\mathrm{Fe}(\mathrm{etx})_{3}$ complex in these solvents.

Then 
Table (1)

Specific rate constant $\left(K_{d}\right)$, the quantum yield $\left(\phi_{d}\right)$ and the reactivity ratio $\left(K_{2} / K_{-1}\right)$ of the $\mathrm{Fe}(\mathrm{etx})_{3}$ complex in different polar organic solvents (irradiation wavelength $365 \mathrm{~nm}$. at $25^{\circ} \mathrm{C}$ ).

\begin{tabular}{|c|c|c|c|c|c|c|}
\hline Solvent & $\begin{array}{c}10^{-7} I_{\text {abs }} \\
\text { Ein. } .^{-1} \cdot S^{-1}\end{array}$ & $\begin{array}{c}10^{-4} \\
{\left[\mathrm{Fe}(\mathrm{etx})_{3}\right]} \\
\mathrm{mol} / \mathrm{l}\end{array}$ & $\begin{array}{c}10^{-5} \\
K_{d} \operatorname{Sec}^{-1}\end{array}$ & $10^{-3} \phi_{d}$ & $\begin{array}{c}10^{-3} \\
K_{2} / K_{-1}\end{array}$ & $\begin{array}{l}\text { Dielectric } \\
\text { constant }\end{array}$ \\
\hline DMSO & 7.32 & 1.21 & 5.78 & 4.78 & 9.22 & 46.45 \\
\hline Methanol & 7.21 & 1.23 & 5.34 & 4.34 & 7.71 & 32.66 \\
\hline Acetone & 7.51 & 1.22 & 5.01 & 4.11 & 7.04 & 20.56 \\
\hline $\begin{array}{c}\text { Ethyl } \\
\text { acetate }\end{array}$ & 6.53 & 1.29 & 4.18 & 5.28 & 4.48 & 6.02 \\
\hline Benzene & 7.22 & 1.18 & 3.22 & 2.73 & 3.73 & 2.27 \\
\hline
\end{tabular}

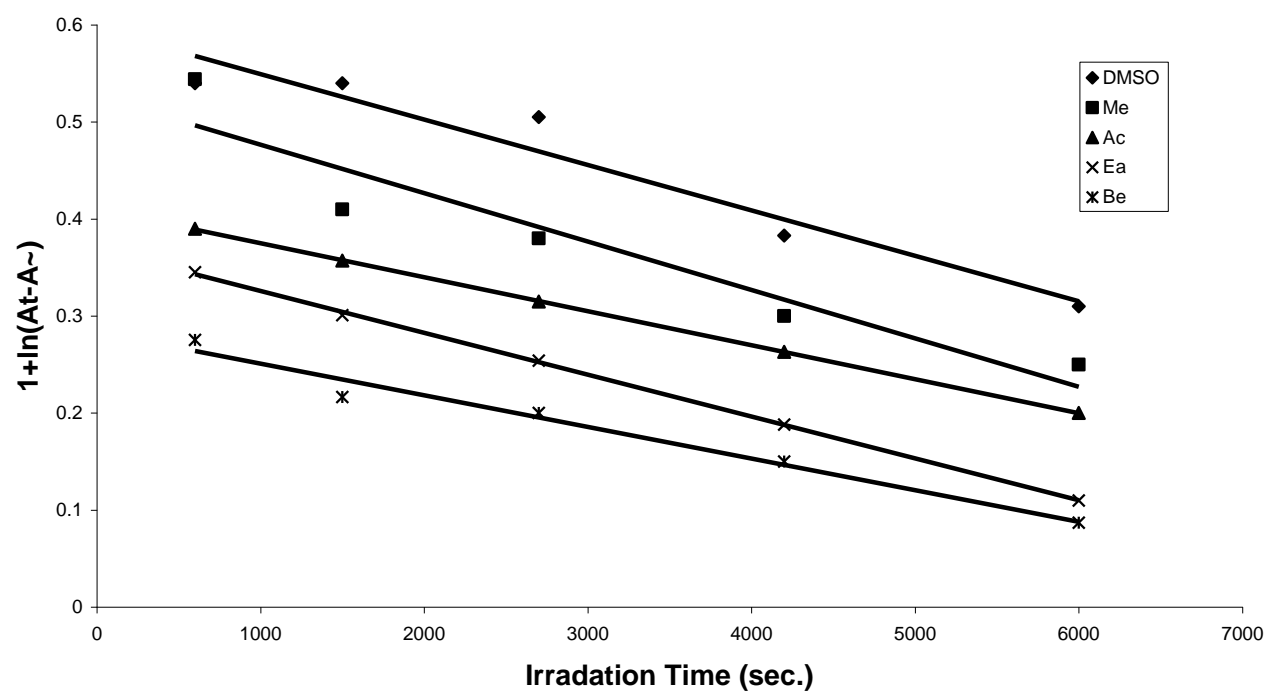

Fig.(1) : Variation of natural logarithm plot of $\mathrm{Fe}(\text { etx })_{3}$ complex with irradiation time in different organic solvents $\left(\lambda_{i r r}=365 \mathrm{~nm}\right.$. At $\left.25^{\circ} \mathrm{C}\right)$.

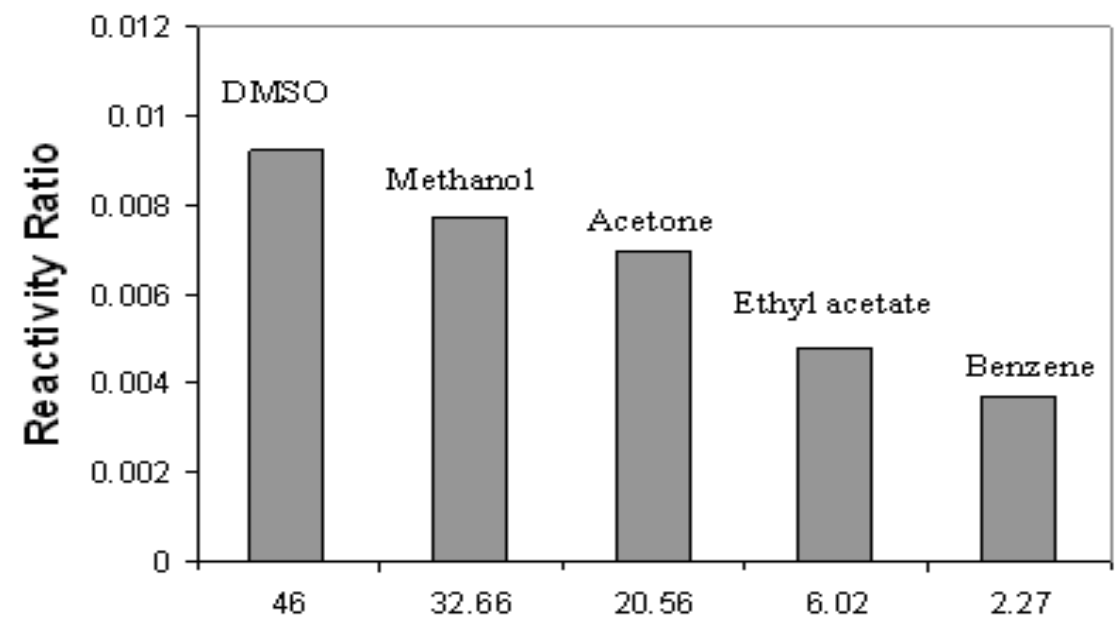

Dielectric Constant

Fig.(2) : Variation in reactivity ratio with the dielectric constant of the solvent, for the photodecomposition of $\mathrm{Fe}(\mathrm{etx})_{3}$ complex in different organic solvents. 


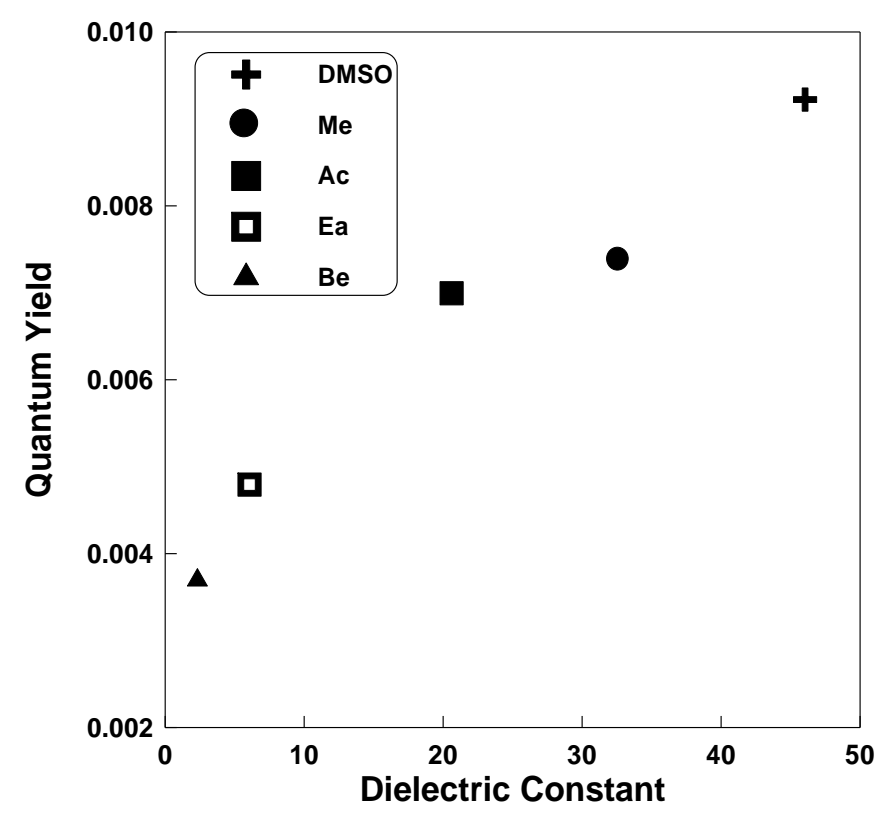

Fig.(3) : Variation in quantum yields $\left(\phi_{d}\right)$ with the dielectric constant of the solvent, for the photodecomposition of $\mathrm{Fe}(\mathrm{etx})_{3}$ complex in different organic solvents.

\section{References}

[1] A.W Adamson and P.D. Fleichauer, "Concepts of Inorganic Photochemistry", John Wily, New York , 1975.

[2] E. Yousif, A. Ameer and S. Aliwi, National J. Chem., 2002, 6, 255.

[3] A.Vogler and H.KunKly, Coord . Chem . Rev ., 2000, 200, 1991.

[4] A.Vogler and H.Kunkely, Coord . Chem . Rev., 2001, 211, 233.

[5] A. Vogler and H. Kunkely, Coord . Chem. Rev, 2000,208, 321.

[6] S.M Aliwi, J.Photochem . Photobiol ., A, 1992, 67, 349 .

[7] S.M.Aliwi, C.H.Bamford and S.U.Mullik, J.Polym . Sci ., Symp ., 1975, 50,330.

[8] B. M. Al-Shimary, M. Sc. Thesis, Al-Mustansiria University (2003).

[9] S.T. Hamdi and S.M. Aliwi . Z.Phs. Chem., $1976,174,199$

[10] V. Carassiti, EPA News Lett., 1983, 20,53.

[11] J. M. Ombab, E. F. Barry, $J$. Chromotogr., 1994, 2,319.

[12] E. A. Yousif, Ph. D. Thesis, Al-Nahrain University (2004).

[13] A. F. Al-Niami, Ph. D. Thesis, Al-Mustansiria University (1999).
[14] O. T. Taha, Ph. D. Thesis, Al-Mustansiria University (2002).

[15] S. M. Aliwi, R. R. Al-ani and D. H. Awad, Iraqi J. Polym.,2003, 2, 107.

[16] A. F. Kazzer, S. E. Al-Mukhtar and I. A. Mustafa, Iraq J. Chem. , 1989, 1, 34.

[17] C. Hatchard and C. Parker. Pro. Roy. Soc. A, 1984, 235, 518.

[18] H. Wood and H. Gest, "Method in Enzymology,"ed. Academic Press, 1986.

[19] "Amrican standard of test method ",D 2324-66, American National standard (1996).

[20] E. Yousif, A. Ameer and S. Aliwi, J. Al-Nahrain Unv., 2002, 4, 44.

\section{الخلاصة}

$$
\text { تم خلال البحث الحالي دراسة الكيمياء الضوئية }
$$

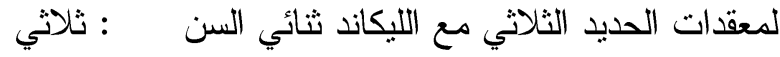

( أثثل زانثيت) في خمسة مذيبات عضوية هي : ثنائي المثيل

سلفو اوكسايد و الميثانول و الأسيتون واسيتات الاثيل

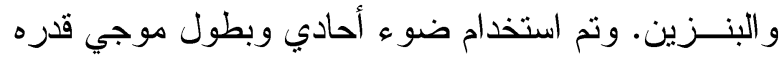

365 نانوميتر وبدرجة حرارة 25ْ ـ لقد دلت التغيرات

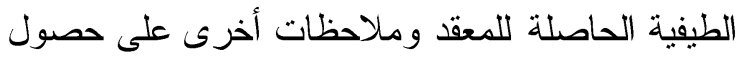


تفاعل من نوع أكسدة-اختز ال داخلي خلال عملية التفاعل الضوئي للمعقد Fe(etx) مع انفصام متجانس للآصرة . Fe-S

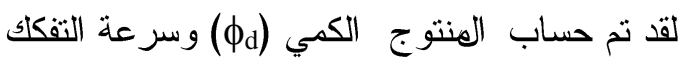
الضوئي ونسبة الفعالية (k2/k-1) في كل مذيب من المذيبات

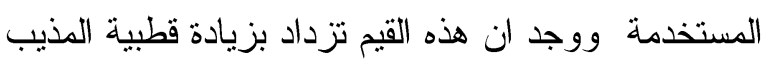

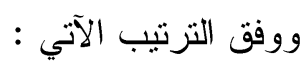
DMSO > Methanol > Acetone > Ethyl acetate > Benzene وطبقاً للنتائج العملية المستحصلة ، تم أقتز اح ميكانيكية التقكل الضوئي لهذه المعقدات تحت الظروف المختبرية المذكورة سابقاً. 